\title{
ROLE OF IMMIGRATION IN AMERICAN SOCIETY'S WELL-BEING
}

Alexander Mechitov, University of Montevallo, Montevallo, Alabama, U.S.A. Helen Moshkovich, University of Montevallo, Montevallo, Alabama, U.S.A.

dx.doi.org/10.18374/JABE-20-3.6

\begin{abstract}
World immigration is on the rise and it has many economic and political ramifications. Since the last presidential campaign in the U.S., immigration has become one of the most debated issues in American politics. This paper analyzes the role of immigrants in American prosperity. First, the paper overviews both historic and current immigration statistics and compares immigration rates in the U.S. with such rates in other developed countries. The paper examines the role and importance of immigrants in different areas of the American economy from hi-tech and digital industries to construction, agriculture and accommodation services. The study also compares American immigration policy with such policies in other countries and argues in favor of the merit-based policy. The paper concludes by emphasizing the positive role of immigration on the American job market and especially the importance of attracting high-skilled specialists for keeping American leading positions in the global economy.
\end{abstract}

Keywords: the U.S. immigration, immigrants in the U.S. economy, immigration policy, immigration visas 